\title{
Empowering Women through Higher Education
}

Singh, Shweta ${ }^{1}$, Sinha, Kanchan Lata $^{1}$ and Agrawal, V. P. ${ }^{2}$

${ }^{1}$ Department of Commerce, S.D.M. Govt. P.G. College, Doiwala, Dehradun, Uttarakhand.

${ }^{2}$ Pt. L.M.S Govt. P. G. College, Rishikesh, Dehradun Uttrakhand

Corresponding Author: nshwetan18@gmail.com; drkanchanlatasinha123@gmail.com

\section{A R T I C L E I N F O}

Received: 25 May 2018 | Accepted: 28 October 2018 | Published Online: 31 December 2018

DOI: $10.31786 / 09756272.18 .9 .2 .203$

EOI: 10.11208/essence.18.9.2.203

Article is an Open Access Publication.

This work is licensed under Attribution-Non Commercial 4.0 International

(https://creativecommons.org/licenses/by/4.0/)

CThe Authors (2018). Publishing Rights @ MANU_ICMANU \& ESSENCE_IJERC.

\section{A B S T R A C T}

Education is the empowerment and the freedom for excellence for the human society. Nevertheless, the role of education in the half of the population of the women folk is lagging behind. It is especially more concern when talks in the sense of women from marginalized section of society, their empowerment, status, position in the society. The aim of higher education is to generate knowledge, encouraging critical thinking and imparting skills relevant to the society determined by its needs. The barrier to education for women in India was the persistent belief that women should not design to talk paid employment although voluntary work was acceptable. Supplement family incomes and today women are well represented in many occupations. However, access to higher education is often restricted for girls who live in rural areas or in towns without colleges or universities. The current study is qualitative in nature and based on secondary data. For this purpose, various government reports, magazine and journals have been used as it is a conceptual paper. Thus, the focus is to know more about the role of higher education in women's life. The primary objective of this study is to know the relevance of higher education in women's life. Furthermore, to identify the obstacle in the path of women empowerment. The author has discussed and evaluated the current status of women in higher education and in respect of their participation in higher education in order to assess the effectiveness of compensatory measure taken by the central and status governments to address the gender-based issues in higher education.

\section{K E Y W O R D S}

Women Empowerment | Population | Higher education

\section{I T A T I O N}

Singh, Shweta; Sinha, Kanchan Lata and Agrawal, V. P. (2018): Empowering Women through Higher Education. ESSENCE Int. J. Env. Rehab. Conserv. IX (1): 17-22.

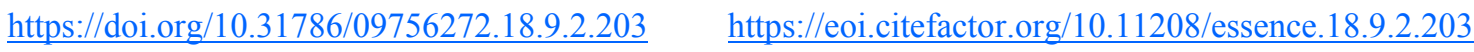




\section{Introduction}

To educate your women first and leave them to themselves, they will tell you what reforms are necessary.... Swami Vivekananda.

In this contemporary world, women need to gain the same amount of power that men have. Now, it is time to forget that men are the only holders of power. In India, women are still facing different obstacles in male-dominated society. Women have generally been looked down upon with disdainful contempt. All sorts of strictures have been inflicted upon them, reducing their status to a mere plaything or a slave of man's whims, a mere chattel to be dumb driven. They have been confined to the hearth and home. The orthodox male-oriented society in India has still not been able to adjust itself to the fresh wave of women's liberation.

But today the times have changed, the Indian woman has cast off her age-old shakes of serfdom and male domination. She has come into her own and started scaling the ladders of social advance with proud dignity. However, Indian women with slow pace are getting empowerment in the sector like education, politics, the work force and even more power within their own households. The worth of civilization can be arbitrated by the place given to women in the society. The work force is covered with intellectual women who currently hold the CEO positions at large companies, which were never held by Indian women. In our country, women have reached a long way eventually and have discovered a new path for them to come. Women's rights are human rights.

Women have a very great part to play in the progress of the country, as the mental and physical contact of women with life is much more lasting and more comprehensive than that of men. To fulfil this goal, women have to get empowered through education, more specifically with higher education. Education can work as the empowerment and the freedom for excellence and intelligence in the whole world. Although, the role of education in the half of the population of the women folk is encountering difficulty. It is particularly more concern when discussed in the sense of women from disregarding section of society, their status, position in the society. Thus the role of higher education for their empowerment has become more certain and anticipating.

Makopadyay (2008) investigated the role of education in the empowerment of women in the District of Malda, west Bengal. The study took in 42 villages of Malda. On the basis of study, it is concluded that women's status is inferior to men's in Malda District. Further, it is found that education emerges as the single most important parameter in empowering women and the path for economic empowerment which can uplifts the status of women.

Bhat (2015) analysed that education is milestone of women empowerment as it provides them to responds to the challenges to confront their traditional role and change in their life. Further, the study added that education is the most powerful tool to change the position of society as it brings a reduction in inequalities and acts as a means of improving their status with the family.

Agrawal and Kukreti (2016) analysed the role of higher education in women empowerment by identifying the greatest hindrance in the path of women empowerment. The study is theoretical in nature and the source of data collection is secondary. On the basis of study, it is concluded that there is no doubt about the essential need of empowering women through higher education. Further, it is mentioned that only literacy is the only solution for empowering women.

Halakerimath and Danappagoudra (2018) studied the empowerment of women through education in the area of Hubli-Dharwad. The sample size of the study was 50 women only. The data collected were tabulated, analyzed by using percentage, 
index and correlation. The findings of the study concluded that to educate women in higher level, improve the social participation and status of women in society. Education provides knowledge of good decision making skill and management resources.

\section{Empowerment}

The Oxford English Dictionary defines "empowerment" as "the action of empowering; the state of being empowered" and it was first used in this form in 1849. Since then, theterm "empowerment" is used across across a wide range of disciplines and each brings different interpretations. Empowerment can be viewed as a way of creating a socially healthy environment in which one can make decisions and make choices, either individually or collectively for social change. The empowerment builds up the inherent ability by way of acquiring knowledge, power and experience (Hashemi Schuler and Riley, 1996).Empowerment is a factor shared by many disciplines and arenas. In recent empowerment literature, the meaning of the term empowerment has often assumed rather than explained or defined. However, some important definitions of empowerment have been mentioned below.

According to Baily (1992) how we precisely define empowerment within our projects and programs will depend majorly on the specific people and context involved. Rappoport (1984) stated that it is easier to define empowerment by its absence, but difficult to define in action as it takes on different forms in different people and contexts. Even defining the concept is subject to debate.

Zimmerman (1984) has noted that asserting a single definition of empowerment may attempt to achieve it formulaic or prescription - like, contradicting the very concept of empowerment.

Therefore, it can be stated that empowerment is the practice of enabling or authorizing individual to think, take action and control work in a self- governing way. It is the procedure by which one can gain control over another's fate and the situations of one's life.

\section{Women Empowerment}

"Woman is the builder and moulder of a nation's destiny. Though delicate and soft as a lily, she has a heart far stronger and bolder than a man, she is the supreme inspiration for the man's onward march, an embodiment of love, pity and compassion, she is no doubt, her commanding personality; nevertheless, is given by solemn"Rabindranath Tagore

Women which nearly constitute half of the population of the country are essential to play vital role in the growth and development of the country. A nation goes ahead only through the contribution of all its members. To realize the dream of becoming a developed country, there is a need for mobilization of women in large numbers by empowering them. Empowerment of women that will have long-term impacts must comprise of consciousness raising before the social structure of gender, which minions women in the family, class, caste, religion, or society, can be improved. Bookman and Morgen (1988) accepted empowerment as the recognition of the forces which act to dominate women and the motivation to change those factors in each woman's life which allow them to act. As Hall (1992) wrote in his literature "It is not the women's purpose to take power from men; rather, the goal of women is to develop their own power while respecting men for who they are" (1992: 104).

\section{Women Empowerment and Higher Education}

International Convention in all forms of Discrimination against Women (ICDAW) in 1993 mentioned that education is one of the most important means of empowering women with knowledge, skills and self-confidence, necessary to participate fully in the development process. Educating women benefit the whole society. It has 
a more significant impact on poverty and development than men's education.

Higher education (such as graduation, postgraduation, professional courses, certificate diploma, Ph.D., etc.) is a discretionary last phase of formally discovering potential in a person. The privilege of access to higher education is referenced in various universal human rights instruments.Higher Education is the aggregate of organized knowledge and practical skills that let theoretical and practicalproblems to be solved by a given type of training, developing and creatively evolving the modern achievements ofscience, technology, and culture. The term "higher education" is as well applied to the training of highly skilled professionals in the fields of economics, science, technology, and culture in various types of higher schools, which accept personswho have successfully completed secondary general-education schools or secondary specialized-education institutions.

\section{Higher Education System in India}

At the time of independence, in 1947, there were only 20 universities and 500 colleges in the country. The number of students and teachers in the higher education system was also very small. But after independence, there has been an exponential increase in all these numbers.

During 2017-18, there were 666 universities, including 129 deemed to be universities recognized by UGC. 313 have been state universities and 175 universities which have not been declared eligible to receive Central Assistance under Section 12(B) of UGC Act

\section{Role of higher education in Empowerment of Women}

Universities should play a keen part in order to achieve the goal of cent per cent literacy in women population. Nevertheless, legislation and policy changes are crucialtowardsstudyof women as theyare equal partner for development of the nation. At higher education level, major roles may take place which is highlighted below:

\section{Scholarships for girls}

Universities should start giving scholarships to the outstanding girls in different disciplines. It will also motivate girls from different societies to come ahead for education and compete with their classmates. These scholarships may be given in those areas where there is a need of girls for the development of society, e.g. nursing, teaching, pathology, pharmacy, etc.

\section{Interaction of universities with girl's school}

Universities should arrange seminars and extra time lectures by the experts in girls' school in different areas. These experts will share with girl students the possibilities of new areas where they can seek admission. Not only this, they will also make aware the girl students about the future need of the different subjects.

\section{Start short term courses for women}

Universities should offer new short-term courses for women like Yoga Education, Nursing, Cutting and Stitching, etc. These courses will help them to start work at their own for their economic independence. Along with it, university degrees will provide them better opportunities in the job market.

\section{Developing relationship with industries}

Universities should start the relationship with different industries. By doing so, the university authorities should apprehend the type of jobs in different areas. Along with it, they can also find out the jobs which are suitable for girls. They can start such courses with the help of different industries. Also, these industries will provide placement to the girl students.

\section{Introducing new professional courses for women}

Universities should introduce new professional courses for women, which they can join after completing their senior secondary education. 
These courses should be from those core areas which are job oriented. After doing these courses either they can go for jobs in offices/institutions or they can do work on their own. The courses like interior decoration, jewellery designing, script writing for TV and radio, computer hardware, technical know-how of electronic gadgets, etc.

\section{Courses in agriculture and allied fields}

Nearly $60 \%$ of India's population are involved and dependent upon agriculture. Undoubtedly, women are also working in the fields. If they are provided training in different aspects of agriculture, they can certainly do wonders in this field also. It will not only increase the productivity of land, but it will also provide monetary gains to the individual/family.

\section{Obstacles in the path of women empowerment}

In the 21stcentury, women began to geteducated and take part in the social, legal economic and political field. Now women are not in boundaries, they are awakeand moving towards progress. In India there is the persistent belief that women should not deign to take paid employment although voluntary work was acceptable. Yet, the census 2011 indicates that the literacy rate of women in India is only $64 \%$, i.e. below the average which is $74 \%$. Lack of education is the root base of women's exploitation andignorance. Only education can help women to know about the rights and duties given in the Indian constitution.furthermore, there are some more obstacles which hinder the empowerment of women. These are discussed below:

\section{Social Norms}

Many societies in India restrict women from leaving the house, given to their orthodox belief and age old traditions. Women in such societies are not allowed to go outside either for education or for employment and are forced to live an isolated and dejected life. Women living under such conditions become accustomed to being inferior to men and are unable to change their present social and economic state.

\section{Workplace Sexual Harassment}

Workplace sexual harassment is the most significant barrier to women empowerment in India. Private sectors like hospitality industry, software industry, educational institutions, and hospitals are some of the worst affected. It is a manifestation of deep rooted male supremacy in the society. There had been a steep rise of about $170 \%$ in the workplace sexual harassment of women in India in the past couple of decades.

\section{Gender discrimination}

Majority of women in India still face gender discrimination at work place as well as in the society. Many societies don't allow the women to go out for employment or education. They are not allowed to take independent decisions either for work or for family, and are treated inferior to men. Such discrimination of the women leads to their socio economic decline and hugely contradicts "Woman Empowerment".

\section{Child Marriage}

Though, India has successfully reduced child marriages in the past few decades, through a number of laws and initiatives taken by the government; still a report in early 2018 by the UNICEF (United Nations Children Emergency Fund) states that nearly 1.5 Million girls in India get married before they turn 18. Early marriage reduces the growth prospects of girls who soon be moving onto adulthood.

\section{Crimes against Women}

Indian women have been subjected to domestic violence and other crimes such as - dowry, honor killing, trafficking etc. It's strange that the women in urban areas are more prone to criminal assault than the women in rural areas. Even working women in big cities avoid using public transport in late hours, fearing their modesty and life. Woman empowerment can only be achieved in 
true sense if we ensure safety of our women, providing them the liberty to roam free and without fear as the men in the society do.

\section{Conclusion}

The emphasis of this study is to know about the role of higher education in women empowerment. Higher education was recognized as a powerful instrument of social- economic advancement of the society in general and a vehicle for upward social mobility for deprived and marginalized sections in particular. The role of higher education in bringing out the importance of women and their position in Indian society. It is especially more concern when talks in the sense of women from marginalized section of society, their empowerment, status, position in the society and the role of education in the higher and other strata of educational fields. The grant or financial support and the support of the family are like a catalyst in bringing the change in the status and position of women in society through the promotion of education. The study also discussed the obstacles such as social norms, workplace sexual harassment, gender discrimination, child marriage, etc. in the path of women empowerment.

\section{References}

Agrawal, D. C. and Kukreti, A. (2016): Role of Higher Education in Women Empowerment in India. Motherhood International Journal of Multidisciplinary Research \& Development, 1(2): 24-29.

Ashford and Lori, S. (1995): gender equality and empowerment of women. Population Bulletin, 50(1): 17-22.

Beijing Documents (1995): The Agenda for Women's Empowerment, Populi, 22(8).

Bhat, R. A. (2015): Role of Education in the Empowement of Women in India. Journal of Education and Practice, 6(10): 188191.
Halakerimath, V. C. and Danappagoudra, S. B. (2018): A Study On Empowerment Of Women Through Education. International Journal of Current Research and Modern Education, 3(1): 393-399.

Makopadyay, H. (2008): The Role of Education in the Empowerment of Women in a District of West Bengal, India: Reflections on a Survey of Women. Journal of International Women's Studies, 10(2): 217-225.

Rapport, J. (1984): Studies In Empowerment: Introduction To The Issue. Prevention in human services, 3: 1-7.

Zimmerman, M. A. (1984): Taking Aim On Empowerment Research: On The Distinction Between Individual And Psychological Conceptions. American journal of community psychology, 18 (1), 169-177. 